\title{
REVIEW
}

\section{Circulating biomarkers that predict incident dementia}

\author{
Galit Weinstein ${ }^{1,2}$ and Sudha Seshadri ${ }^{1,2^{*}}$
}

\begin{abstract}
Dementia is currently diagnosed based on clinical symptoms and signs, but significant brain damage has already occurred by the time a clinical diagnosis of dementia is made, and it is increasingly recognized that this may be too late for any effective intervention. It would therefore be of great public health and preventive value to define a variety of biomarkers that could permit early detection of persons at a higher risk for developing dementia, and specifically dementia due to Alzheimer's disease. Nevertheless, for the purpose of large-scale screening, circulating biomarkers are more appropriate because they are less invasive than lumbar puncture, less costly than brain amyloid imaging and can be easily assessed repeatedly in a primary care clinic setting. In this brief review we will review a number of candidate molecules implicated as possible predictors of dementia risk. These candidates include markers of vascular injury, metabolic and inflammatory states, amyloid and tau pathway markers, measures of neural degeneration and repair efforts, and other molecules that might contribute to anatomical and functional changes characteristic of dementia and Alzheimer's disease.
\end{abstract}

\section{Introduction}

The lifetime risk of dementia is one in five [1], with an estimated prevalence of 24 million people worldwide. As the population ages, the number of people with dementia is projected to rise to over 80 million by 2040, leading to a substantial public health burden [2]. Currently, dementia is diagnosed based on clinical characteristics $[3,4]$ but brain imaging and cerebrospinal fluid (CSF) markers are thought to improve diagnostic sensitivity and specificity, especially with regard to the etiology of the dementia [5]. However, significant brain damage has already occurred by the time a clinical diagnosis of dementia is made, and it is increasingly recognized that this may be too late for any effective intervention. It is therefore of great importance to define biomarkers that could permit early detection of apparently normal persons who are at a higher risk for developing dementia. A better understanding of the biomarker signature that precedes the clinical manifestation of dementia, and specifically dementia due to Alzheimer's disease (AD),

\footnotetext{
* Correspondence: suseshad@bu.edu

'Department of Neurology, Boston University School of Medicine, B602, 72 East Concord Street, Boston, MA 02118, USA

${ }^{2}$ Framingham Heart Study, 73 Mount Wayte Avenue, Framingham, MA 01702, USA
}

would permit the identification of a high-risk group of individuals who could be preferentially enrolled in studies testing preventive interventions. The biomarkers might also serve as easily assessable targets to gauge the efficacy of any interventions. Finally, identifying novel biomarkers could also point to new biological pathways that may play a role in early dementia and identify druggable targets and endophenotypes for genetic studies.

Indeed, there have been persistent efforts in recent years to identify novel biomarkers for incident dementia and AD; these could be thought of as predictors of future risk or as markers of an early, preclinical pathological process [6,7]. A biomarker may be broadly defined as a characteristic that is objectively measured and evaluated as an indicator of normal biological or pathogenic processes, or of pharmacologic responses to a therapeutic intervention. The biomarker could be a marker of a disease trait, state or rate and could be a genetic variant, a molecule measurable in a body fluid or tissue, or an imaging or performance (cognition, gait) measure.

Genetic markers, notably the apolipoprotein E (APOE) $\varepsilon 4$ genotype, are known to increase the risk of developing $\mathrm{AD}$, the exact magnitude of increase varying depending on the age of the person (relative risk varying from no increase among centenarians to a twofold to fourfold 
increase in 65 year olds), sex of the person (relative risk being higher in women), number of copies of the $\varepsilon 4$ allele and presence of other concomitant risk markers [8]. Several other, recently identified genetic variants have also been associated with risk of $\mathrm{AD}$, but their additive value to risk prediction over age, sex and $A P O E$ genotype is low; this is largely because the effect of each nonAPOE gene is small, ranging from a 12 to $30 \%$ increase in risk $[9,10]$. CSF levels of beta-amyloid $\left(A \beta_{40}\right.$ and $A \beta_{42}$ isoforms), tau and phospho-tau have been associated with risk of $\mathrm{AD}$, and other CSF molecules may further improve risk stratification [11,12]. Brain amyloid imaging techniques [13] are also promising. Nevertheless, for the purpose of large-scale screening, circulating biomarkers are more appropriate because they are less invasive than lumbar puncture to assess CSF, less costly than brain amyloid imaging using positron emission tomography and can be easily assessed repeatedly in a population or primary care clinic setting.

In this brief review we will focus on biomarkers associated with risk of clinical dementia and $\mathrm{AD}$, both in persons who appear to be cognitively normal and in those who have mild cognitive impairment (MCI); we will not be addressing markers associated solely with cognitive decline outcomes not severe enough to be categorized as dementia. We will examine circulating markers measured in whole blood, plasma or serum but will not reference markers assayed only in circulating platelets, monocytes or other blood cell types.

There are many factors that impact levels of circulating markers, such as whether samples were collected in a fasting state or in a recumbent or erect posture, whether plasma or serum samples were utilized, and technical factors such as the rapidity of aliquoting and freezing samples and details of the assay used. The most useful circulating biomarkers are likely to be relatively stable across testing conditions, easy to measure precisely and reproducibly (low intra-assay and inter-assay coefficients $<5$ to $10 \%$ ) and to have fairly significant effect sizes (hazard ratios $>1.5$ ).

A circulating biomarker that is useful in risk prediction need not be either causal or protective, changes in the level of this risk marker might be an epiphenomenon of early disease-related changes. Thus two overlapping but not congruent goals are to identify a set of biomarkers that improve clinical risk prediction models based on demographic and clinical measures alone, and to identify potentially causal pathways that may be amenable to intervention regardless of whether or not these biomarkers improve risk prediction. Hence, we will begin with a broad overview of various classes of circulating biomarkers that have been linked to incident dementia, mainly in large prospective cohort studies, but will also highlight markers most likely to incrementally improve risk prediction.

\section{Overview}

Circulating biomarkers may reflect brain pathology since about $500 \mathrm{ml}$ CSF is absorbed into blood daily [14], circulating molecules can impact brain structure and function, and the pathology of $\mathrm{AD}$ may be associated with changes in the blood-brain barrier that increase the movement of molecules between the blood and the brain parenchyma; for example, mechanisms such as inflammation are both apparent in plasma and are associated with AD [15]. Peripheral blood monocytes and exosomes traverse the blood-brain barrier and systemic changes can affect the macrocirculation and microcirculation and internal milieu of the brain. Based on our current knowledge of the pathophysiological pathways underlying $\mathrm{AD}$, on tissue and animal models of $\mathrm{AD}$, and on a few agnostic approaches such as genome-wide genetic studies and omics-based (proteomics, metabolomics, transcriptomics and microRNA) searches, a number of candidate circulating biomarkers have been identified and their value in predicting dementia and $\mathrm{AD}$ assessed. Based on a review of the current literature (summarized below and in Additional file 1), some biomarkers to be considered for inclusion in such a panel of circulating biomarkers would probably include markers of lipid pathways, vascular injury, metabolic and inflammatory states, amyloid and tau pathway markers, measures of neural degeneration and repair efforts, and other molecules that might reflect neurotransmission, endocrine function or as yet unknown pathways that contribute to anatomical and clinical changes in dementia and AD.

\section{Biomarkers associated with vascular risk, metabolic and inflammation states}

Various lipid pathways are involved in neuronal function and in the metabolism of $A \beta$ and tau. Several lipid pathway genes, notably $A P O E, A P O J(C L U)$, SORL1, and perhaps also SORT1 and CETP, have been linked to risk of AD [16,17]. Hence several candidate lipids, lipoproteins and related molecules have been examined as putative biomarkers of incident AD.

\section{Total cholesterol}

The relationship between total cholesterol levels and risk of dementia is still uncertain and appears to depend on the age at cholesterol measurement [18]. When measured in midlife, substantial evidence supports an association between total cholesterol and dementia risk [19-22], although some studies did not find such an association [23-26]. On the other hand, late-life total cholesterol is inversely related to subsequent risk of dementia $[27,28]$ or no association has been observed $[29,30]$. Cholesterol, as a key component of the neuronal membrane, plays many roles in neuronal function and regulation [31]. Evidence from cell culture and animal 
studies demonstrate that the production, aggregation, deposition and recycling of cerebral $A \beta$ as well as its neurotoxicity may be modulated by cholesterol $[32,33]$. However, we still do not have a complete understanding of how cholesterol levels can influence AD pathogenesis, and despite early evidence from observational studies that cholesterol lowering by statins might reduce the risk of dementia, this was not corroborated in clinical trials.

\section{Oxysterols}

The brain eliminates excess cholesterol by excreting two oxidized oxysterols into the circulation: 24Shydroxycholesterol and 27-hydroxycholesterol [34]. Levels of 24S-hydroxycholesterol appear to reflect brain production (and number of neurons) as well as hepatic elimination. Although evidence suggests that oxysterols play a role in AD pathogenesis by interacting with $A \beta$ and regulating astrocytic production of $\mathrm{APOE}$, the precise mechanisms are not clear [35] and data on the association of circulating oxysterols with incident dementia are scarce [36]. In a recent study of 105 older participants, those with higher plasma 24-hydroxycholesterol and a greater ratio of 24-hydroxycholesterol/27-hydroxycholesterol were more likely to develop incident cognitive impairment over 8 years of follow-up [36].

\section{Other lipoproteins, and sphingolipids}

A variety of lipoproteins have been examined for possible association with risk of dementia and $\mathrm{AD}$, including high-density lipoprotein cholesterol, low-density lipoprotein cholesterol, small dense low-density lipoprotein, lipoprotein a, apolipoprotein A1 and apolipoprotein B variants, but the only ones that have shown a fairly convincing association, albeit inconsistently, are higher levels of low-density lipoprotein and lower levels of high-density lipoprotein $(<55 \mathrm{mg} / \mathrm{dl})$ [28,37]. Apolipoprotein $J$ (also called clusterin) will be discussed later in this article.

Sphingolipids, including ceramide, sphingomyelin and glycosphingolipids, are major components of lipid rafts and may play a role in processing of amyloid precursor protein. Higher ceramide levels may also increase oxidative stress and have been associated with an increased risk of $\mathrm{AD}$ [38].

\section{Homocysteine, vitamins $B_{12}$ and folate, and related metabolites}

It has long been known that cobalamin (vitamin $\mathrm{B}_{12}$ ) deficiency in pernicious anemia was associated with dementia [39], and Lindenbaum and colleagues showed that cognitive decline could be present in the absence of anemia [40]. Circulating vitamin $B_{12}$ levels measure both active vitamin $B_{12}$ bound to transcobalamin (holotranscobalamin) and inactive vitamin $B_{12}$ bound to haptocorrin, and hence circulating vitamin $B_{12}$ levels often correlated poorly with cellular vitamin $B_{12}$ status. Plasma homocysteine and methylmalonic acid, and more recently holotranscobalamin, have been shown to be better indicators of vitamin $B_{12}$ status and associated with risk of incident dementia and $\mathrm{AD}[41,42]$.

Homocysteine is a sulfur-containing amino acid produced in the methionine cycle and there is some evidence that it may increase the risk of $A D$ independent of its status as a marker of low vitamin $B_{12}$. Hyperhomocysteinemia is associated with higher age, male gender, renal dysfunction, genetic disposition, high methionine intake, and deficiencies of folate, vitamin $\mathrm{B}_{12}$ and pyridoxine vitamins $[43,44]$. Considerable evidence suggests that an elevation of total plasma homocysteine (tHcy) is associated with a subsequent higher risk of AD [45-48], but contradictory evidence also exists [49-51]. A prospective evaluation of 1,092 dementia-free Framingham Heart study participants demonstrated that elevations in plasma tHcy over 8 years prior to the onset of clinical dementia predicted the subsequent development of AD. A plasma tHcy level in the highest age-specific and sexspecific quartile doubled the risk of developing dementia or AD after adjustment for age, sex, and APOE $\varepsilon 4$ genotype. A similar effect was noted in The Conselice Study of Brain Aging, which followed 816 subjects for over 4 years, although the Washington-Heights Inwood Columbia Aging Project did not find a significant association, perhaps because the mean plasma tHcy level was high in this study, even among control subjects.

The mechanisms underlying this association remain uncertain and it is not clear whether tHcy is an AD risk factor or merely a risk marker [52]. However, there are many potential pathways that could explain this association. Homocysteine is an essential intermediary in the metabolism of methionine to the S-adenosylmethionine compound. S-adenosylmethionine serves as the methyl donor for all methylation reactions within the neuron, including the methylation of phospholipids, proteins, myelin, catecholamines and nucleic acids. Homocysteine treatment of cell cultures doubles the rate of telomere shortening [53]. Homocysteine also promotes calcium influx and generation of toxic free oxygen radicals, thus accelerating DNA damage within hippocampal neurons [54,55]. A metabolite of homocysteine, homocysteic acid, activates excitotoxic glutamatergic $N$-methyl-D-aspartate receptors [56,57]. Elevated tHcy levels promote the homocysteinylation of proteins, thus altering protein function [58,59], and inhibit $\mathrm{Na}^{+} / \mathrm{K}^{+}$-ATPase activity [60]. Homocysteine increases presenilin-mediated $A \beta$ generation [61] and potentiates the neurotoxicity of insoluble $A \beta$ deposits [54,62], and also promotes tau hyperphosphorylation [63]. Homocysteine could increase dementia risk via its vasculotoxic effects on large arteries 
because it alters low-density lipoprotein receptor function, stimulates vascular smooth muscle proliferation, increases atherosclerotic plaque, reduces endothelial reactivity, and has prothrombotic and procoagulant effects [64]. Homocysteine also alters cerebral capillary function in folate-deficient rats [65].

\section{Insulin and amylin}

Diabetes is associated with a higher risk of dementia [66], and one of the suggested underlying mechanisms is through dysfunction in insulin signaling pathways in the brain since peripheral and perhaps central insulin resistance is a defining characteristic of type 2 diabetes [67]. Typically hyperinsulinemia correlates closely with measures of insulin resistance such as the Homeostasis Model of Assessment - Insulin Resistance, which factors in simultaneous glucose and insulin levels. However, the mechanisms underlying the insulin-dementia association are not clear, and may include decreased clearance of $A \beta$ by the insulin-degrading enzyme (which preferentially binds insulin but has a physiological role in $A \beta$ clearance), increased tau hyperphosphorylation, or an indirect effect such as potentiating vascular injury or the adverse effects of inflammation [68].

In a longitudinal analysis of 683 people without dementia followed for 5.4 years, the risk of AD doubled in persons with hyperinsulinemia and the association was even stronger among APOE $\varepsilon 4$ allele carriers [69]. Similarly, in another study, impaired insulin response to a glucose tolerance test in mid-life was associated with an increased risk of $\mathrm{AD} 32$ years later, but fasting serum insulin was associated with risk of AD only in APOE $\varepsilon 4$ allele carriers [70]. Interestingly, both low and high serum insulin levels were associated with an increased risk of incident dementia in the Honolulu-Asia study [71], and in the Rotterdam study the risk of $\mathrm{AD}$ increased in persons with high serum levels of insulin after a 3-year follow-up period - but this association was no longer apparent with a longer followup, so the association is complex rather than straightforward, and may vary depending on the amount of concurrent vascular pathology, APOE or inflammatory status and across stages of the disease [72]. Amylin, or islet amyloid polypeptide, an amyloidogenic peptide hormone produced by the pancreas along with insulin, was recently shown to be present in the brains of persons with $\mathrm{AD}$ [73], but a prospective association of circulating amylin levels and risk of AD has not been demonstrated.

\section{Adiponectin}

Adiponectin is an adipokine hormone (secreted by adipose tissue), and low levels of adiponectin have been linked to increased insulin resistance and to the development of coronary heart disease [74], stroke [75] and type 2 diabetes [76]. On the other hand, higher levels have been associated with an increased risk of all-cause mortality [77] and visceral obesity has been linked to smaller brain volumes and a higher risk of $\mathrm{AD}$ [78]. Increased levels of adiponectin in the plasma have been recently shown to be an independent risk factor for all-cause dementia and $\mathrm{AD}$ in women over a mean follow-up of 13 years [79]. The unexpected inverse association may reflect a compensatory elevation of adipokine levels in response to early AD pathology, but it has also been inversely related to weight loss that often precedes the onset of clinical dementia.

\section{Leptin}

Leptin is a hormone produced by subcutaneous and visceral adipose tissue that regulates food intake, satiety and body weight. Accumulating evidence suggests that this hormone also plays a pivotal role, perhaps by improving hippocampal synaptic plasticity, in modulating higher cognitive functions such as learning and memory, and that dysfunction in this system may be linked to neurodegenerative diseases such as AD [80]. Leptin has been shown to reduce tau hyperphosphorylation and to attenuate the toxic effect of $A \beta$ levels in neurons [80]. Lower leptin levels were associated with greater brain atrophy $[81,82]$ and leptin dysfunction may provide a biological link between obesity and dementia [83]. In the Framingham study, the inverse association of leptin levels with risk of $\mathrm{AD}$ was only seen in persons who were not obese, perhaps due to the leptin resistance known to be present in obese persons.

Few observational studies have examined the association between plasma leptin levels and risk of incident dementia or $\mathrm{AD}$. In a subsample of the Framingham study participants (mean age 79 years), circulating leptin was inversely related to risk of incident dementia and AD after a median follow-up of 8 years [82]. However in a subsequent study of almost 2,000 Swedish women, leptin levels measured in mid-life (38 to 60 years old) were not associated with the risk of incident dementia occurring up to 32 years later [84].

\section{C-reactive protein and interleukin-6}

Inflammation is increasingly recognized as a key component in cerebrovascular diseases [85] and neurodegenerative diseases [86] and may play a fundamental role in dementia pathogenesis [87]. Cross-sectional studies suggest that inflammatory proteins such as C-reactive protein and interleukin- 6 are elevated in the blood of individuals with $\mathrm{AD}$ compared with controls $[88,89]$, but with cross-sectional studies it remains unclear whether inflammation is a byproduct of the AD pathology or is directly contributing to brain damage and cognitive deficits. Prospective studies, however, are inconsistent.

The Honolulu-Asia Aging Study demonstrated a threefold increase in risk of dementia over a follow-up of 25 years in 
men with a circulating C-reactive protein level in the top three quartiles, compared with the lowest quartile [90]. Associations of C-reactive protein and interleukin- 6 with risk of incident dementia were also demonstrated in the Rotterdam study [91], and in The Conselice Study of Brain Aging only a combination of C-reactive protein and interleukin-6 predicted vascular dementia but not AD [92]. Other largescale prospective studies failed to demonstrate such associations. Framingham Heart Study data suggest that whereas circulating levels of C-reactive protein, interleukin-6, interleukin-1 and tumor necrosis factor alpha were not associated with the risk of developing $\mathrm{AD}$, higher spontaneous production of interleukin-1 or tumor necrosis factor alpha by peripheral blood mononuclear cells (which readily traverse the blood-brain barrier) may be a marker for future risk of $\mathrm{AD}[79,93,94]$.

\section{Thyroid stimulating hormone}

Clinical thyroid disease, causing either hyperthyroidism or hypothyroidism, is well known to result in cognitive changes, but these states may not be related to risk of $\mathrm{AD}$ dementia [95]. However, an association of variation in thyroid stimulating hormone (TSH) with risk of incident AD has been described. In a first prospective study of older persons free of thyroid disease, a more than threefold increase in risk of dementia and AD was observed in persons with a reduced circulating TSH level at baseline [96]. In the Framingham Heart Study, over a longer follow-up period of more than 12 years, both low and high TSH levels were associated with an increased risk of developing incident $\mathrm{AD}$ in women but not in men [97]. Another study of 93 people with MCI demonstrated an association between reduced TSH levels and increased risk of conversion to AD [98]. However, some prospective studies failed to find associations between TSH levels and risk of dementia or AD among persons free of clinical thyroid disease $[99,100]$.

Elevations in circulating TSH could be secondary to low thyroid hormone levels, which can directly increase amyloid precursor protein expression and consequently $A \beta$ levels. On the other hand, the effect of elevated TSH on a normal thyroid is to increase thyroid hormone levels, which can result in increased oxidative stress. Both low and high thyroid hormone levels are associated with accelerated systemic atherosclerosis $[101,102]$. Indeed, in a recent prospective study of older individuals, increased TSH levels were not associated with incident $\mathrm{AD}$ but were associated with a higher risk of incident vascular dementia [100].

\section{Biomarkers associated with Alzheimer's disease and neurodegenerative pathology Beta-amyloid}

The deposition of $A \beta$ in senile plaques in the brain is a hallmark of $A D$ [103]. Peptides $A \beta_{40}$ and $A \beta_{42}$ are the two major components in these plaques and are generated by cleavage of amyloid precursor protein [104]. The relationship between brain and plasma $A \beta$ proteins is complex [105], and studies relating plasma $A \beta$ levels to incident AD have been inconclusive [106-115]. Reports on the ability of plasma $A \beta_{40}$ and $A \beta_{42}$ levels (and their ratio) to predict conversion from $\mathrm{MCI}$ to $\mathrm{AD}$ or to correlate with cognitive decline in people with $\mathrm{AD}$ or $\mathrm{MCI}$ are also mixed [116-118]. Nevertheless, results of a recent meta-analysis suggest that higher baseline $A \beta_{40}$ and $A \beta_{42}$ levels in cognitively normal older individuals might be predictors of higher rates of progression to AD or dementia [119]. This association is discussed in detail in a companion article [120].

\section{Apolipoprotein E}

APOE $\varepsilon 4$ allele is the most significant and best validated genetic risk factor for sporadic AD [8]. However, no consistent association has been demonstrated between serum levels of APOE and either incident or prevalent $\mathrm{AD}$ [121] or cognitive decline among persons with $\mathrm{MCI}$ or cognitively intact persons [122].

\section{Clusterin}

A variant within the clusterin $(C L U)$ or apolipoprotein J gene has been associated with low plasma clusterin levels and with increased risk of $\mathrm{AD}$ in genome-wide association studies [123]. On the other hand, plasma clusterin levels are increased in $\mathrm{AD}$ and $\mathrm{MCI}$ patients $[122,124]$ and a dose-dependent association has been demonstrated with increasing disease severity [124,125]. In the Rotterdam study, plasma clusterin levels were not associated with risk of incident dementia - although among persons with $\mathrm{AD}$, higher clusterin levels were associated with a more severe dementia [124]. Moreover, although the plasma concentration of clusterin was found to be associated with rate of clinical progression in AD patients in a combined proteomic and neuroimaging study [125], a subsequent study failed to demonstrate such an association [122].

Clusterin may contribute to $\mathrm{AD}$ pathogenesis through various mechanisms, and reviewing these it appears likely that elevation in clusterin levels is probably a compensatory response to early $\mathrm{AD}$ pathology. Clusterin shares structural and functional similarities with heat shock proteins, can bind amyloid extracellularly and may inhibit the aggregation of $A \beta$ monomers into toxic oligomers (an extracellular chaperone function). Clusterin may also reduce the neurotoxicity of amyloid through its interaction with molecules involved in signal transduction (transforming growth factor-beta receptors) and DNA repair (Ku70 and Ku86 proteins) [126,127], and may be a key player in regulation of the cell cycle and apoptosis $[127,128]$. Further, as the second major apolipoprotein in the brain, clusterin is involved 
in cholesterol transport and neuronal lipid metabolism. Clusterin may also inhibit neuroinflammation, which, in turn, is thought to be a major contributor in $\mathrm{AD}$ pathogenesis.

\section{Other promising biomarkers}

A variety of other plasma proteins seems promising and merit further study. These candidates include: proteins linked to AD pathophysiological processes (such as beta-site amyloid precursor protein-cleaving enzyme 1, transthyretin, butyrylcholinesterase and choline acetyltransferase); markers of neuronal injury (such as neuron-specific enolase), of astroglial injury (glial fibrillary acid protein), of oligodendroglial injury (S-100), of myelin injury (such as myelin basic protein), and of endothelial and matrix function (such as vascular endothelial growth factor and matrix metallopeptidase-9); levels of vitamins, such as vitamin D (lower levels of which have been associated with risk of cardiovascular disease, cognitive decline and with prevalent but not incident dementia) [129] and vitamin E; neurotrophic factors that are involved in neuronal growth, development and synaptic plasticity and whose circulating levels change with lifestyle (diet and physical activity), for example brain-derived neurotrophic factor, beta-nerve growth factor and insulinlike growth factor-1; and protein products of genes identified via genome-wide association studies and candidate gene studies.

\section{Biomarkers discovered by agnostic approaches (proteomics, metabolomics, and so forth)}

Proteomics technology enables the comprehensive analysis of the protein composition of a biological sample at a given time. A recent study that aimed to detect changes due to $\mathrm{AD}$ in a comprehensive panel of plasma proteins identified five proteins that were able to distinguish between $\mathrm{AD}$ and controls, but these data need validation in additional prospective studies [130].

\section{Integrating plasma biomarkers for a holistic approach to dementia risk prediction}

An ideal circulating biomarker should be accurately, validly and reproducibly measurable using a relatively low-cost assay. The circulating biomarker should have a discernible impact on dementia/AD risk that is either independent of or synergistic with the effect of other putative biomarkers. Consistency of effect across age, sex and race/ethnicity and ability to be incorporated in a multiplex platform would be an advantage but are not essential. Of course, we are not just concerned with the association of the biomarker with disease, what we wish to know is whether incorporating information regarding the biomarker improves the predictive accuracy of the best available clinical model (standard of care) incorporating several known predictors such as age, sex and APOE genotype. Improvement in predictive accuracy can be assessed as a change in the $\mathrm{C}$ statistic or as the integrated discrimination improvement or net reclassification improvement $[98,99]$. The latter examines whether addition of biomarker data improves correct reclassification of persons in an intermediate risk category into low-risk or high-risk categories. Such estimates have not been calculated for most of the putative biomarkers discussed and would, of course, vary based on the study sample selected. Effect sizes for individual biomarkers range from 20 to $200 \%$ and are in a range wherein single markers are unlikely to substantially improve risk predictions based on age, sex and APOE genotype.

Selecting which biomarkers should be included in prospective assessments of a multimarker panel is not easy, but there are guidelines developed from studies in cancer and cardiovascular disease [100]. Correlation between putative biomarkers should be examined, and among moderately or highly correlated pairs of biomarkers biological and statistical information should be used to select biomarkers that appear most biologically relevant and have the larger impact on risk in ageadjusted and sex-adjusted models. Imaging (magnetic resonance imaging, positron emission tomography), functional imaging (functional magnetic resonance imaging) and cognitive endophenotypes will also be useful in studying the utility of individual biomarkers and biomarker panels. Bioinformatics and machine-learning algorithms have also been used to design biomarker panels $[101,102]$. The challenges inherent in identifying circulating biomarkers (often by showing differences in levels among persons with AD compared with controls), in validating them in prospective cohorts as useful risk markers for development of clinical dementia in normal older persons or persons with MCI and in crafting multi-marker panels were initially addressed by a working group jointly convened by the Ronald and Nancy Reagan Research Institute of the Alzheimer's Association [131] and the National Institute on Aging, and are currently being readdressed by a Blood-based Biomarker Interest Group within the Alzheimer's Disease Neuroimaging Initiative [120]. A few early attempts have been made to identify such multimarker panels, and in a study of 17 circulating biomarkers, which included only one of the four markers suggested above, four biomarkers (apoE, B-type natriuretic peptide, C-reactive protein and pancreatic polypeptide) were found to be associated with risk of AD; this multimarker panel has not yet been studied in incident cohorts [132]. Another paper used data-mining approaches to the published literature and identified five likely candidates including a novel one, urokinase-type plasminogen activator receptor [133]. 


\section{Conclusion}

Circulating biomarkers are easy to measure repeatedly and can typically be estimated at a lower cost than imaging studies. A number of circulating (plasma, serum or blood) biomarkers have been shown to have different levels in persons with dementia, typically due to $\mathrm{AD}$, when such persons are compared with normal individuals and with persons with MCI. Some of these markers, but not all, are also associated with the risk of developing incident dementia in population studies - however, age-specific, sex-specific, ethnicity-specific, and diseasestage-specific effects appear to exist, and hence results are often equivocal. Variability in assays and intraindividual variation over time are additional challenges. Further, the identification of these biomarkers has, hitherto, been based on our existing knowledge regarding dementia/AD pathophysiology, and agnostic omicsbased approaches are just emerging. However, several plasma biomarkers such as $A \beta_{42}$ and $A \beta_{40}$ (and their ratio), homocysteine, insulin (or insulin resistance) and leptin levels may be useful as part of a multimarker panel to predict, along with age, sex, $A P O E$ and perhaps other genetic variants, the risk of developing dementia. Over the next decade, a number of multimarker panels of five to 50 potential circulating dementia biomarkers will probably be developed and tested in various ongoing studies of preclinical and prodromal dementia and AD.

Note: This article is part of a series on Peripheral Biomarkers, edited by Douglas Galasko. Other articles in this series can be found at http://alzres.com/series/biomarkers.

\section{Additional file}

Additional file 1: Tables S1 and S2 present plasma biomarkers that predict incident dementia.

\section{Abbreviations \\ AD: Alzheimer's disease; APOE: Apolipoprotein E; Aß: beta-amyloid; CSF: Cerebrospinal fluid; MCl: Mild cognitive impairment; tHcy: total plasma homocysteine; TSH: Thyroid stimulating hormone.}

\section{Competing interests}

The authors declare that they have no competing interests.

\footnotetext{
Acknowledgements

This review was supported by grants from the National Institute of Neurological Disorders and Stroke (NS17950), the National Heart, Lung and Blood Association (HL93029, U01HL 096917) and the National Institute of Aging (AG08122, AG16495, AG033193, AG031287, P30AG013846). The content is solely the responsibility of the authors and does not necessarily represent the official views of the National Institute of Neurological Disorders and Stroke, the National Heart Lung and Blood Institute, the National Institute of Aging or the National Institutes of Health.
}

\section{References}

1. Seshadri S, Wolf PA: Lifetime risk of stroke and dementia: current concepts, and estimates from the Framingham Study. Lancet Neurol 2007, 6:1106-1114.

2. Ferri CP, Prince M, Brayne C, Brodaty H, Fratiglioni L, Ganguli M, Hall K, Hasegawa K, Hendrie H, Huang Y, Jorm A, Mathers C, Menezes PR, Rimmer E, Scazufca M: Global prevalence of dementia: a Delphi consensus study. Lancet 2005, 366:2112-2117.

3. Diagnostic and Statistical Manual of Mental Disorders: DSM-IV. 4th edition. Washington, DC: American Psychiatric Association; 1994.

4. McKhann GM, Knopman DS, Chertkow H, Hyman BT, Jack CR Jr, Kawas CH, Klunk WE, Koroshetz WJ, Manly JJ, Mayeux R, Mohs RC, Morris JC, Rossor MN, Scheltens P, Carrillo MC, Thies B, Weintraub S, Phelps CH: The diagnosis of dementia due to Alzheimer's disease: recommendations from the National Institute on Aging-Alzheimer's Association workgroups on diagnostic guidelines for Alzheimer's disease. Alzheimers Dement 2011, 7:263-269.

5. Dubois B, Feldman HH, Jacova C, Dekosky ST, Barberger-Gateau P, Cummings J, Delacourte A, Galasko D, Gauthier S, Jicha G, Meguro K, O'Brien J, Pasquier F, Robert P, Rossor M, Salloway S, Stern Y, Visser PJ, Scheltens P: Research criteria for the diagnosis of Alzheimer's disease: revising the NINCDS-ADRDA criteria. Lancet Neurol 2007 , 6:734-746.

6. Bazenet C, Lovestone S: Plasma biomarkers for Alzheimer's disease: much needed but tough to find. Biomark Med 2012, 6:441-454

7. Song F, Poljak A, Smythe GA, Sachdev P: Plasma biomarkers for mild cognitive impairment and Alzheimer's disease. Brain Res Rev 2009, 61:69-80.

8. Farrer LA, Cupples LA, Haines JL, Hyman B, Kukull WA, Mayeux R, Myers RH, Pericak-Vance MA, Risch N, van Duijn CM: Effects of age, sex, and ethnicity on the association between apolipoprotein E genotype and Alzheimer disease. A meta-analysis. APOE and Alzheimer Disease Meta Analysis Consortium. JAMA 1997, 278:1349-1356.

9. Patterson C, Feightner JW, Garcia A, Hsiung GY, MacKnight C, Sadovnick AD: Diagnosis and treatment of dementia: 1 . Risk assessment and primary prevention of Alzheimer disease. CMAJ 2008, 178:548-556.

10. Seshadri S, Fitzpatrick AL, Ikram MA, DeStefano AL, Gudnason V, Boada M, Bis JC, Smith AV, Carassquillo MM, Lambert JC, Harold D, Schrijvers EM, Ramirez-Lorca R, Debette S, Longstreth WT Jr, Janssens AC, Pankratz VS, Dartigues JF, Hollingworth P, Aspelund T, Hernandez I, Beiser A, Kuller LH, Koudstaal PJ, Dickson DW, Tzourio C, Abraham R, Antunez C, Du Y, Rotter Jl, et al: Genome-wide analysis of genetic loci associated with Alzheimer disease. JAMA 2010, 303:1832-1840.

11. Molinuevo JL, Sanchez-Valle R, Llado A, Fortea J, Bartres-Faz D, Rami L: Identifying earlier Alzheimer's disease: insights from the preclinical and prodromal phases. Neurodegener Dis 2012, 10:158-160.

12. Fagan $A M$, Perrin RJ: Upcoming candidate cerebrospinal fluid biomarkers of Alzheimer's disease. Biomark Med 2012, 6:455-476.

13. Herholz K: Use of FDG PET as an imaging biomarker in clinical trials of Alzheimer's disease. Biomark Med 2012, 6:431-439.

14. Hye A, Lynham S, Thambisetty M, Causevic M, Campbell J, Byers HL, Hooper C, Rijsdijk F, Tabrizi SJ, Banner S, Shaw CE, Foy C, Poppe M, Archer N, Hamilton G, Powell J, Brown RG, Sham P, Ward M, Lovestone S: Proteome-based plasma biomarkers for Alzheimer's disease. Brain 2006, 129:3042-3050.

15. Wyss-Coray T: Inflammation in Alzheimer disease: driving force, bystander or beneficial response? Nat Med 2006, 12:1005-1015.

16. Rogaeva E, Meng Y, Lee JH, Gu Y, Kawarai T, Zou F, Katayama T, Baldwin CT, Cheng R, Hasegawa H, Chen F, Shibata N, Lunetta KL, Pardossi-Piquard R, Bohm C, Wakutani Y, Cupples LA, Cuenco KT, Green RC, Pinessi L, Rainero I, Sorbi S, Bruni A, Duara R, Friedland RP, Inzelberg R, Hampe W, Bujo H, Song YQ, Andersen OM, et al: The neuronal sortilin-related receptor SORL1 is genetically associated with Alzheimer disease. Nat Genet 2007, 39:168-177.

17. Sanders AE, Wang C, Katz M, Derby CA, Barzilai N, Ozelius L, Lipton RB: Association of a functional polymorphism in the cholesteryl ester transfer protein (CETP) gene with memory decline and incidence of dementia. JAMA 2010, 303:150-158.

18. Anstey KJ, Lipnicki DM, Low LF: Cholesterol as a risk factor for dementia and cognitive decline: a systematic review of prospective studies with meta-analysis. Am J Geriatr Psychiatry 2008, 16:343-354.

19. Kivipelto M, Helkala EL, Laakso MP, Hanninen T, Hallikainen M, Alhainen K, livonen S, Mannermaa A, Tuomilehto J, Nissinen A, Soininen $\mathrm{H}$ : Apolipoprotein E epsilon4 allele, elevated midlife total cholesterol level, and high midlife systolic blood pressure are independent risk factors for late-life Alzheimer disease. Ann Intern Med 2002, 137:149-155. 
20. Notkola IL, Sulkava R, Pekkanen J, Erkinjuntti T, Ehnholm C, Kivinen P, Tuomilehto J, Nissinen A: Serum total cholesterol, apolipoprotein E epsilon 4 allele, and Alzheimer's disease. Neuroepidemiology 1998, 17:14-20.

21. Solomon A, Kivipelto M, Wolozin B, Zhou J, Whitmer RA: Midlife serum cholesterol and increased risk of Alzheimer's and vascular dementia three decades later. Dement Geriatr Cogn Disord 2009, 28:75-80.

22. Whitmer RA, Sidney S, Selby J, Johnston SC, Yaffe K: Midlife cardiovascular risk factors and risk of dementia in late life. Neurology 2005, 64:277-281.

23. Kalmijn S, Foley D, White L, Burchfiel CM, Curb JD, Petrovitch H, Ross GW, Havlik RJ, Launer LJ: Metabolic cardiovascular syndrome and risk of dementia in Japanese-American elderly men. The Honolulu-Asia aging study. Arterioscler Thromb Vasc Biol 2000, 20:2255-2260

24. Mielke MM, Zandi PP, Shao H, Waern M, Ostling S, Guo X, Bjorkelund C, Lissner L, Skoog I, Gustafson DR: The 32-year relationship between cholesterol and dementia from midlife to late life. Neurology 2010, 75:1888-1895.

25. Stewart $R$, White $L R$, Xue QL, Launer LJ: Twenty-six-year change in total cholesterol levels and incident dementia: the Honolulu-Asia Aging Study. Arch Neurol 2007, 64:103-107.

26. Tan ZS, Seshadri S, Beiser A, Wilson PW, Kiel DP, Tocco M, D'Agostino RB, Wolf PA: Plasma total cholesterol level as a risk factor for Alzheimer disease: the Framingham Study. Arch Intern Med 2003, 163:1053-1057.

27. Mielke MM, Zandi PP, Sjogren M, Gustafson D, Ostling S, Steen B, Skoog I: High total cholesterol levels in late life associated with a reduced risk of dementia. Neurology 2005, 64:1689-1695.

28. Reitz C, Tang MX, Luchsinger J, Mayeux R: Relation of plasma lipids to Alzheimer disease and vascular dementia. Arch Neurol 2004, 61:705-714.

29. Li G, Shofer JB, Kukull WA, Peskind ER, Tsuang DW, Breitner JC, McCormick W, Bowen JD, Teri L, Schellenberg GD, Larson EB: Serum cholesterol and risk of Alzheimer disease: a community-based cohort study. Neurology 2005, 65:1045-1050

30. Yoshitake T, Kiyohara Y, Kato I, Ohmura T, Iwamoto H, Nakayama K, Ohmor S, Nomiyama K, Kawano H, Ueda K, Sueishi K, Tsuneyoshi M, Fujishima M: Incidence and risk factors of vascular dementia and Alzheimer's disease in a defined elderly Japanese population: the Hisayama Study. Neurology 1995, 45:1161-1168.

31. Pfrieger FW: Cholesterol homeostasis and function in neurons of the central nervous system. Cell Mol Life Sci 2003, 60:1158-1171.

32. Di Paolo G, Kim TW: Linking lipids to Alzheimer's disease: cholesterol and beyond. Nat Rev Neurosci 2011, 12:284-296.

33. Maulik M, Westaway D, Jhamandas JH, Kar S: Role of cholesterol in APP metabolism and its significance in Alzheimer's disease pathogenesis. Mol Neurobiol 2013, 47:37-63.

34. Bjorkhem I, Cedazo-Minguez A, Leoni V, Meaney S: Oxysterols and neurodegenerative diseases. Mol Aspects Med 2009, 30:171-179.

35. Gamba P, Testa G, Sottero B, Gargiulo S, Poli G, Leonarduzzi G: The link between altered cholesterol metabolism and Alzheimer's disease. Ann N Y Acad Sci 2012, 1259:54-64.

36. Hughes TM, Kuller LH, Lopez OL, Becker JT, Evans RW, Sutton-Tyrrell K, Rosano C: Markers of cholesterol metabolism in the brain show stronger associations with cerebrovascular disease than Alzheimer's disease. J Alzheimers Dis 2012, 30:53-61.

37. Reitz C, Tang MX, Schupf N, Manly JJ, Mayeux R, Luchsinger JA: Association of higher levels of high-density lipoprotein cholesterol in elderly individuals and lower risk of late-onset Alzheimer disease. Arch Neurol 2010, 67:1491-1497.

38. Mielke MM, Bandaru W, Haughey NJ, Xia J, Fried LP, Yasar S, Albert M, Varma V, Harris G, Schneider EB, Rabins PV, Bandeen-Roche K, Lyketsos CG, Carlson MC: Serum ceramides increase the risk of Alzheimer disease: the Women's Health and Aging Study II. Neurology 2012, 79:633-641.

39. Herbert V: Cobalamin deficiency and neuropsychiatric disorders. N Engl Med 1988, 319:1733-1735.

40. Lindenbaum J, Healton EB, Savage DG, Brust JC, Garrett TJ, Podell ER, Marcell PD, Stabler SP, Allen RH: Neuropsychiatric disorders caused by cobalamin deficiency in the absence of anemia or macrocytosis. $N$ Engl $J$ Med 1988, 318:1720-1728.

41. Hooshmand B, Solomon A, Kareholt I, Leiviska J, Rusanen M, Ahtiluoto S, Winblad B, Laatikainen T, Soininen H, Kivipelto M: Homocysteine and holotranscobalamin and the risk of Alzheimer disease: a longitudinal study. Neurology 2010, 75:1408-1414.
42. O'Leary F, Allman-Farinelli M, Samman S: Vitamin $B_{12}$ status, cognitive decline and dementia: a systematic review of prospective cohort studies. $\mathrm{Br}$ J Nutr 2012, 108:1948-1961.

43. Saw SM, Yuan JM, Ong CN, Arakawa K, Lee HP, Coetzee GA, Yu MC: Genetic, dietary, and other lifestyle determinants of plasma homocysteine concentrations in middle-aged and older Chinese men and women in Singapore. Am J Clin Nutr 2001, 73:232-239.

44. Arnadottir M, Hultberg B, Nilsson-Ehle P, Thysell H: The effect of reduced glomerular filtration rate on plasma total homocysteine concentration. Scand J Clin Lab Invest 1996, 56:41-46.

45. Haan MN, Miller JW, Aiello AE, Whitmer RA, Jagust WJ, Mungas DM, Allen $\mathrm{LH}$, Green R: Homocysteine, B vitamins, and the incidence of dementia and cognitive impairment: results from the Sacramento Area Latino Study on Aging. Am J Clin Nutr 2007, 85:511-517.

46. Kim JM, Stewart R, Kim SW, Shin IS, Yang SJ, Shin HY, Yoon JS: Changes in folate, vitamin B12 and homocysteine associated with incident dementia. J Neurol Neurosurg Psychiatry 2008, 79:864-868.

47. Ravaglia G, Forti P, Maioli F, Martelli M, Servadei L, Brunetti N, Porcellini E, Licastro F: Homocysteine and folate as risk factors for dementia and Alzheimer disease. Am J Clin Nutr 2005, 82:636-643.

48. Seshadri S, Beiser A, Selhub J, Jacques PF, Rosenberg IH, D'Agostino RB, Wilson PW, Wolf PA: Plasma homocysteine as a risk factor for dementia and Alzheimer's disease. N Engl J Med 2002, 346:476-483.

49. Kalmijn S, Launer LJ, Lindemans J, Bots ML, Hofman A, Breteler MM: Total homocysteine and cognitive decline in a community-based sample of elderly subjects: the Rotterdam Study. Am J Epidemiol 1999, 150:283-289.

50. Luchsinger JA, Tang MX, Shea S, Miller J, Green R, Mayeux R: Plasma homocysteine levels and risk of Alzheimer disease. Neurology 2004, 62:1972-1976.

51. Reitz C, Tang MX, Miller J, Green R, Luchsinger JA: Plasma homocysteine and risk of mild cognitive impairment. Dement Geriatr Cogn Disord 2009, 27:11-17.

52. Seshadri S: Elevated plasma homocysteine levels: risk factor or risk marker for the development of dementia and Alzheimer's disease? J Alzheimers Dis 2006, 9:393-398.

53. Xu D, Neville R, Finkel T: Homocysteine accelerates endothelial cell senescence. FEBS Lett 2000, 470:20-24.

54. Kruman II, Kumaravel TS, Lohani A, Pedersen WA, Cutler RG, Kruman Y, Haughey N, Lee J, Evans M, Mattson MP: Folic acid deficiency and homocysteine impair DNA repair in hippocampal neurons and sensitize them to amyloid toxicity in experimental models of Alzheimer's disease. J Neurosci 2002, 22:1752-1762.

55. Ho PI, Ortiz D, Rogers E, Shea TB: Multiple aspects of homocysteine neurotoxicity: glutamate excitotoxicity, kinase hyperactivation and DNA damage. J Neurosci Res 2002, 70:694-702.

56. Lehmann J, Tsai C, Wood PL: Homocysteic acid as a putative excitatory amino acid neurotransmitter: I. Postsynaptic characteristics at N-methylD-aspartate-type receptors on striatal cholinergic interneurons. J Neurochem 1988, 51:1765-1770.

57. Benz B, Grima G, Do KQ: Glutamate-induced homocysteic acid release from astrocytes: possible implication in glia-neuron signaling. Neuroscience 2004, 124:377-386.

58. Medina M, Urdiales JL, Amores-Sanchez Ml: Roles of homocysteine in cell metabolism: old and new functions. Eur J Biochem 2001, 268:3871-3882.

59. Jakubowski H: Protein homocysteinylation: possible mechanism underlying pathological consequences of elevated homocysteine levels. Faseb J 1999, 13:2277-2283.

60. Streck EL, Zugno Al, Tagliari B, Wannmacher C, Wajner M, Wyse AT: Inhibition of $\mathrm{Na}+, \mathrm{K}+-$ ATPase activity by the metabolites accumulating in homocystinuria. Metab Brain Dis 2002, 17:83-91.

61. Sai X, Kawamura Y, Kokame K, Yamaguchi H, Shiraishi H, Suzuki R, Suzuki T, Kawaichi M, Miyata T, Kitamura T, De Strooper B, Yanagisawa K, Komano H: Endoplasmic reticulum stress-inducible protein, Herp, enhances presenilin-mediated generation of amyloid beta-protein. J Biol Chem 2002, 277:12915-12920.

62. White AR, Huang X, Jobling MF, Barrow CJ, Beyreuther K, Masters CL, Bush Al, Cappai R: Homocysteine potentiates copper- and amyloid beta peptide-mediated toxicity in primary neuronal cultures: possible risk factors in the Alzheimer's-type neurodegenerative pathways. J Neurochem 2001, 76:1509-1520.

63. Vafai SB, Stock JB: Protein phosphatase 2A methylation: a link between elevated plasma homocysteine and Alzheimer's disease. FEBS Lett 2002, 518:1-4. 
64. Welch GN, Loscalzo J: Homocysteine and atherothrombosis. N Engl J Med 1998, 338:1042-1050.

65. Kim JM, Lee $H$, Chang N: Hyperhomocysteinemia due to short-term folate deprivation is related to electron microscopic changes in the rat brain. J Nutr 2002, 132:3418-3421.

66. Biessels GJ, Staekenborg S, Brunner E, Brayne C, Scheltens P: Risk of dementia in diabetes mellitus: a systematic review. Lancet Neurol 2006, 5:64-74.

67. Giordano V, Peluso G, lannuccelli M, Benatti $P$, Nicolai $R$, Calvani M: Systemic and brain metabolic dysfunction as a new paradigm for approaching Alzheimer's dementia. Neurochem Res 2007, 32:555-567.

68. Craft S: The role of metabolic disorders in Alzheimer disease and vascular dementia: two roads converged. Arch Neurol 2009, 66:300-305.

69. Luchsinger JA, Tang MX, Shea S, Mayeux R: Hyperinsulinemia and risk of Alzheimer disease. Neurology 2004, 63:1187-1192.

70. Ronnemaa E, Zethelius B, Sundelof J, Sundstrom J, Degerman-Gunnarsson M, Berne C, Lannfelt L, Kilander L: Impaired insulin secretion increases the risk of Alzheimer disease. Neurology 2008, 71:1065-1071.

71. Peila $R$, Rodriguez $B L$, White $L R$, Launer $\amalg$ : Fasting insulin and incident dementia in an elderly population of Japanese-American men. Neurology 2004, 63:228-233.

72. Schrijvers EM, Witteman JC, Sijbrands EJ, Hofman A, Koudstaal PJ, Breteler MM: Insulin metabolism and the risk of Alzheimer disease: the Rotterdam Study. Neurology 2010, 75:1982-1987.

73. Jackson K, Barisone GA, Diaz E, Jin LW, Decarli C, Despa F: Amylin deposition in the brain: a second amyloid in Alzheimer disease? Ann Neurol 2013 [Epub ahead of print]

74. Sattar N, Wannamethee G, Sarwar N, Tchernova J, Cherry L, Wallace AM, Danesh J, Whincup PH: Adiponectin and coronary heart disease: a prospective study and meta-analysis. Circulation 2006, 114:623-629.

75. Kim BJ, Lee SH, Ryu WS, Kim CK, Yoon BW: Adipocytokines and ischemic stroke: differential associations between stroke subtypes. J Neurol Sci 2012, 312:117-122

76. Li S, Shin HJ, Ding EL, van Dam RM: Adiponectin levels and risk of type 2 diabetes: a systematic review and meta-analysis. JAMA 2009, 302:179-188.

77. Wannamethee SG, Whincup PH, Lennon L, Sattar N: Circulating adiponectin levels and mortality in elderly men with and without cardiovascular disease and heart failure. Arch Intern Med 2007, 167:1510-1517.

78. Debette S, Beiser A, Hoffmann U, Decarli C, O'Donnell CJ, Massaro JM, Au R, Himali JJ, Wolf PA, Fox CS, Seshadri S: Visceral fat is associated with lower brain volume in healthy middle-aged adults. Ann Neurol 2010, 68:136-144.

79. van Himbergen TM, Beiser AS, Ai M, Seshadri S, Otokozawa S, Au R, Thongtang N, Wolf PA, Schaefer EJ: Biomarkers for insulin resistance and inflammation and the risk for all-cause dementia and Alzheimer disease: results from the Framingham Heart Study. Arch Neurol 2012, 69:594-600

80. Beccano-Kelly D, Harvey J: Leptin: a novel therapeutic target in Alzheimer's disease? Int J Alzheimers Dis 2012, 2012:594137.

81. Rajagopalan P, Toga AW, Jack CR, Weiner MW, Thompson PM: Fat-massrelated hormone, plasma leptin, predicts brain volumes in the elderly. Neuroreport 2013, 24:58-62.

82. Lieb W, Beiser AS, Vasan RS, Tan ZS, Au R, Harris TB, Roubenoff R, Auerbach S, DeCarli C, Wolf PA, Seshadri S: Association of plasma leptin levels with incident Alzheimer disease and MRI measures of brain aging. JAMA 2009, 302:2565-2572.

83. Lee EB: Obesity, leptin, and Alzheimer's disease. Ann N Y Acad Sci 2011, 1243:15-29.

84. Gustafson DR, Backman K, Lissner L, Carlsson L, Waern M, Ostling S, Guo X, Bengtsson C, Skoog I: Leptin and dementia over 32 years - the Prospective Population Study of Women. Alzheimers Dement 2012, 8:272-277.

85. Sullivan GW, Sarembock IJ, Linden J: The role of inflammation in vascular diseases. J Leukoc Biol 2000, 67:591-602.

86. Amor S, Puentes F, Baker D, van der Valk P: Inflammation in neurodegenerative diseases. Immunology 2010, 129:154-169.

87. Gorelick PB: Role of inflammation in cognitive impairment: results of observational epidemiological studies and clinical trials. Ann N Y Acad Sci 2010, 1207:155-162.

88. Strandberg TE, Tilvis RS: C-reactive protein, cardiovascular risk factors, and mortality in a prospective study in the elderly. Arterioscler Thromb Vasc Biol 2000, 20:1057-1060.
89. Kalman J, Juhasz A, Laird G, Dickens P, Jardanhazy T, Rimanoczy A, Boncz I, Parry-Jones $W L$, Janka Z: Serum interleukin- 6 levels correlate with the severity of dementia in Down syndrome and in Alzheimer's disease. Acta Neurol Scand 1997, 96:236-240.

90. Schmidt R, Schmidt H, Curb JD, Masaki K, White LR, Launer LJ: Early inflammation and dementia: a 25-year follow-up of the Honolulu-Asia Aging Study. Ann Neurol 2002, 52:168-174.

91. Engelhart MJ, Geerlings MI, Meijer J, Kiliaan A, Ruitenberg A, van Swieten JC, Stijnen T, Hofman A, Witteman JC, Breteler MM: Inflammatory proteins in plasma and the risk of dementia: the Rotterdam study. Arch Neurol 2004, 61:668-672.

92. Ravaglia G, Forti P, Maioli F, Chiappelli M, Montesi F, Tumini E, Mariani E, Licastro F, Patterson C: Blood inflammatory markers and risk of dementia: The Conselice Study of Brain Aging. Neurobiol Aging 2007, 28:1810-1820.

93. Sundelof J, Kilander L, Helmersson J, Larsson A, Ronnemaa E, DegermanGunnarsson M, Basun H, Lannfelt L, Basu S: Systemic inflammation and the risk of Alzheimer's disease and dementia: a prospective populationbased study. J Alzheimers Dis 2009, 18:79-87.

94. Tan ZS, Beiser AS, Vasan RS, Roubenoff R, Dinarello CA, Harris TB, Benjamin EJ, Au R, Kiel DP, Wolf PA, Seshadri S: Inflammatory markers and the risk of Alzheimer disease: the Framingham Study. Neurology 2007, 68:1902-1908.

95. Lopez O, Huff FJ, Martinez AJ, Bedetti CD: Prevalence of thyroid abnormalities is not increased in Alzheimer's disease. Neurobiol Aging 1989, 10:247-251.

96. Kalmijn S, Mehta KM, Pols HA, Hofman A, Drexhage HA, Breteler MM: Subclinical hyperthyroidism and the risk of dementia. The Rotterdam study. Clin Endocrinol (Oxf) 2000, 53:733-737.

97. Tan ZS, Beiser A, Vasan RS, Au R, Auerbach S, Kiel DP, Wolf PA, Seshadri S: Thyroid function and the risk of Alzheimer disease: the Framingham Study. Arch Intern Med 2008, 168:1514-1520.

98. Annerbo S, Wahlund LO, Lokk J: The significance of thyroid-stimulating hormone and homocysteine in the development of Alzheimer's disease in mild cognitive impairment: a 6-year follow-up study. Am J Alzheimers Dis Other Demen 2006, 21:182-188.

99. de Jong FJ, den Heijer T, Visser TJ, de Rijke YB, Drexhage HA, Hofman A, Breteler MM: Thyroid hormones, dementia, and atrophy of the medial temporal lobe. J Clin Endocrinol Metab 2006, 91:2569-2573.

100. Forti P, Olivelli V, Rietti E, Maltoni B, Pirazzoli G, Gatti R, Gioia MG, Ravaglia G: Serum thyroid-stimulating hormone as a predictor of cognitive impairment in an elderly cohort. Gerontology 2012, 58:41-49.

101. Gan EH, Pearce SH: Clinical review: the thyroid in mind: cognitive function and low thyrotropin in older people. J Clin Endocrinol Metab 2012, 97:3438-3449.

102. Tan ZS, Vasan RS: Thyroid function and Alzheimer's disease. J Alzheimers Dis 2009, 16:503-507.

103. Selkoe DJ: Alzheimer's disease: a central role for amyloid. J Neuropathol Exp Neurol 1994, 53:438-447.

104. Selkoe DJ: Normal and abnormal biology of the beta-amyloid precursor protein. Annu Rev Neurosci 1994, 17:489-517.

105. Castellano JM, Deane R, Gottesdiener AJ, Verghese PB, Stewart FR, West T, Paoletti AC, Kasper TR, DeMattos RB, Zlokovic BV, Holtzman DM: Lowdensity lipoprotein receptor overexpression enhances the rate of brainto-blood A $\beta$ clearance in a mouse model of beta-amyloidosis. Proc Natl Acad Sci U S A 2012, 109:15502-15507.

106. Graff-Radford NR, Crook JE, Lucas J, Boeve BF, Knopman DS, Ivnik RJ, Smith GE, Younkin LH, Petersen RC, Younkin SG: Association of low plasma $A \beta 42$ $A \beta 40$ ratios with increased imminent risk for mild cognitive impairment and Alzheimer disease. Arch Neurol 2007, 64:354-362.

107. Hansson O, Stomrud E, Vanmechelen E, Ostling S, Gustafson DR, Zetterberg $\mathrm{H}$, Blennow K, Skoog I: Evaluation of plasma $A \beta$ as predictor of Alzheimer's disease in older individuals without dementia: a populationbased study. J Alzheimers Dis 2012, 28:231-238.

108. Lambert JC, Schraen-Maschke S, Richard F, Fievet N, Rouaud O, Berr C, Dartigues JF, Tzourio C, Alperovitch A, Buee L, Amouyel P: Association of plasma amyloid beta with risk of dementia: the prospective Three-City Study. Neurology 2009, 73:847-853.

109. Mayeux R, Honig LS, Tang MX, Manly J, Stern Y, Schupf N, Mehta PD: Plasma $A \beta 40$ and $A \beta 42$ and Alzheimer's disease: relation to age, mortality, and risk. Neurology 2003, 61:1185-1190.

110. Mayeux R, Tang MX, Jacobs DM, Manly J, Bell K, Merchant C, Small SA, Stern Y, Wisniewski HM, Mehta PD: Plasma amyloid beta-peptide 1-42 and incipient Alzheimer's disease. Ann Neurol 1999, 46:412-416. 
111. Schupf N, Tang MX, Fukuyama H, Manly J, Andrews H, Mehta P, Ravetch J, Mayeux R: Peripheral $A \beta$ subspecies as risk biomarkers of Alzheimer's disease. Proc Natl Acad Sci U S A 2008, 105:14052-14057.

112. Shah NS, Vidal JS, Masaki K, Petrovitch H, Ross GW, Tilley C, DeMattos RB, Tracy RP, White LR, Launer LJ: Midlife blood pressure, plasma betaamyloid, and the risk for Alzheimer disease: the Honolulu Asia Aging Study. Hypertension 2012, 59:780-786.

113. Sundelof J, Giedraitis V, Irizarry MC, Sundstrom J, Ingelsson E, Ronnemaa E, Arnlov J, Gunnarsson MD, Hyman BT, Basun H, Ingelsson M, Lannfelt L, Kilander L: Plasma beta amyloid and the risk of Alzheimer disease and dementia in elderly men: a prospective, population-based cohort study. Arch Neurol 2008, 65:256-263.

114. van Oijen $M$, Hofman $A$, Soares HD, Koudstaal PJ, Breteler MM: Plasma $A \beta_{1-40}$ and $A \beta_{1-42}$ and the risk of dementia: a prospective case-cohort study. Lancet Neurol 2006, 5:655-660.

115. Lopez OL, Kuller LH, Mehta PD, Becker JT, Gach HM, Sweet RA, Chang YF, Tracy R, DeKosky ST: Plasma amyloid levels and the risk of AD in normal subjects in the Cardiovascular Health Study. Neurology 2008, 70:1664-1671.

116. Fukumoto H, Tennis M, Locascio JJ, Hyman BT, Growdon JH, Irizarry MC: Age but not diagnosis is the main predictor of plasma amyloid betaprotein levels. Arch Neurol 2003, 60:958-964.

117. Hansson $\mathrm{O}$, Zetterberg $H$, Vanmechelen $E$, Vanderstichele $H$, Andreasson $U$, Londos $E$, Wallin A, Minthon L, Blennow K: Evaluation of plasma $A \beta_{40}$ and $A \beta_{42}$ as predictors of conversion to Alzheimer's disease in patients with mild cognitive impairment. Neurobiol Aging 2010, 31:357-367.

118. Locascio JJ, Fukumoto H, Yap L, Bottiglieri T, Growdon JH, Hyman BT, Irizarry MC: Plasma amyloid beta-protein and C-reactive protein in relation to the rate of progression of Alzheimer disease. Arch Neurol 2008, 65:776-785

119. Song F, Poljak A, Valenzuela M, Mayeux R, Smythe GA, Sachdev PS: Metaanalysis of plasma amyloid-beta levels in Alzheimer's disease. J Alzheimers Dis 2011, 26:365-375.

120. Henriksen K, O'Bryant SE, Hampel H, Trojanowski JQ, Montine TJ, Jeromin A, Blennow K, Lonneborg A, Wyss-Coray T, Soares H, Bazenet C, Sjogren M, Hu W, Lovestone S, Karsdal MA, Weiner MW: The future of blood-based biomarkers for Alzheimer's disease. Alzheimers Dement 2013 [Epub ahead of print].

121. Slooter AJ, de Knijff P, Hofman A, Cruts M, Breteler MM, Van Broeckhoven C, Havekes LM, van Duijn CM: Serum apolipoprotein E level is not increased in Alzheimer's disease: the Rotterdam study. Neurosci Lett 1998, 248:21-24.

122. Song F, Poljak A, Crawford J, Kochan NA, Wen W, Cameron B, Lux O, Brodaty H, Mather K, Smythe GA, Sachdev PS: Plasma apolipoprotein levels are associated with cognitive status and decline in a community cohort of older individuals. PLOS One 2012, 7:e34078.

123. Lambert JC, Heath S, Even G, Campion D, Sleegers K, Hiltunen M, Combarros O, Zelenika D, Bullido MJ, Tavernier B, Letenneur L, Bettens K, Berr C, Pasquier F, Fievet N, Barberger-Gateau P, Engelborghs S, De Deyn P, Mateo I, Franck A, Helisalmi S, Porcellini E, Hanon O, de Pancorbo MM, Lendon C, Dufouil C, Jaillard C, Leveillard T, Alvarez V, Bosco P, et al: Genome-wide association study identifies variants at CLU and CR1 associated with Alzheimer's disease. Nat Genet 2009, 41:1094-1099.

124. Schrijvers EM, Koudstaal PJ, Hofman A, Breteler MM: Plasma clusterin and the risk of Alzheimer disease. JAMA 2011, 305:1322-1326.

125. Thambisetty M, Simmons A, Velayudhan L, Hye A, Campbell J, Zhang Y, Wahlund LO, Westman E, Kinsey A, Guntert A, Proitsi P, Powell J, Causevic M, Killick R, Lunnon K, Lynham S, Broadstock M, Choudhry F, Howlett DR, Williams RJ, Sharp SI, Mitchelmore C, Tunnard C, Leung R, Foy C, O'Brien D, Breen G, Furney SJ, Ward M, Kloszewska I, et al: Association of plasma clusterin concentration with severity, pathology, and progression in Alzheimer disease. Arch Gen Psychiatry 2010, 67:739-748.

126. Holtzman DM: In vivo effects of ApoE and clusterin on amyloid-beta metabolism and neuropathology. J Mol Neurosci 2004, 23:247-254.

127. Nuutinen T, Suuronen T, Kauppinen A, Salminen A: Clusterin: a forgotten player in Alzheimer's disease. Brain Res Rev 2009, 61:89-104.

128. Yu JT, Tan L: The role of clusterin in Alzheimer's disease: pathways, pathogenesis, and therapy. Mol Neurobio/ 2012, 45:314-326.

129. Pogge E: Vitamin D and Alzheimer's disease: is there a link? Consult Pharm 2010, 25:440-450
130. Guo LH, Alexopoulos P, Wagenpfeil S, Kurz A, Perneczky R: Plasma proteomics for the identification of Alzheimer disease. Alzheimer Dis Assoc Disord 2013 [Epub ahead of print].

131. The Ronald and Nancy Reagan Research Institute of the Alzheimer's Association, National Institute on Aging Working Group: Consensus report of the Working Group on: 'Molecular and Biochemical Markers of Alzheimer's Disease'. The Ronald and Nancy Reagan Research Institute of the Alzheimer's Association and the National Institute on Aging Working Group. Neurobiol Aging 1998, 19:109-116.

132. Hu WT, Holtzman DM, Fagan AM, Shaw LM, Perrin R, Arnold SE, Grossman M, Xiong C, Craig-Schapiro R, Clark CM, Pickering E, Kuhn M, Chen Y, Van Deerlin VM, McCluskey L, Elman L, Karlawish J, Chen-Plotkin A, Hurtig HI, Siderowf A, Swenson F, Lee VM, Morris JC, Trojanowski JQ, Soares H: Plasma multianalyte profiling in mild cognitive impairment and Alzheimer disease. Neurology 2012, 79:897-905.

133. Greco I, Day N, Riddoch-Contreras J, Reed J, Soininen H, Kloszewska I, Tsolaki M, Vellas B, Spenger C, Mecocci P, Wahlund LO, Simmons A, Barnes J, Lovestone S: Alzheimer's disease biomarker discovery using in silico literature mining and clinical validation. J Trans/ Med 2012, 10:217.

10.1186/alzrt235

Cite this article as: Weinstein and Seshadri: Circulating biomarkers that predict incident dementia. Alzheimer's Research \& Therapy 2014, 6:6 